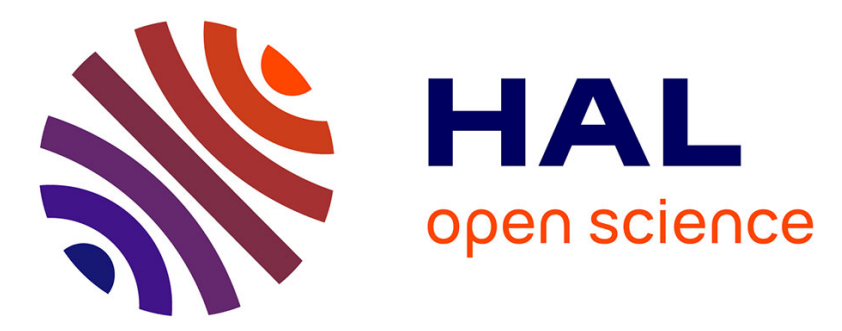

\title{
Field models for the prediction of leaf infection and latent period of Fusicladium oleagineum on olive based on rain, temperature and relative humidity
}

Christophe Roubal, S. Regis, Philippe C. Nicot

\section{- To cite this version:}

Christophe Roubal, S. Regis, Philippe C. Nicot. Field models for the prediction of leaf infection and latent period of Fusicladium oleagineum on olive based on rain, temperature and relative humidity. Plant Pathology, 2013, 62 (3), pp.657-666. 10.1111/j.1365-3059.2012.02666.x . hal-02650753

\section{HAL Id: hal-02650753 \\ https: / hal.inrae.fr/hal-02650753}

Submitted on 29 May 2020

HAL is a multi-disciplinary open access archive for the deposit and dissemination of scientific research documents, whether they are published or not. The documents may come from teaching and research institutions in France or abroad, or from public or private research centers.
L'archive ouverte pluridisciplinaire HAL, est destinée au dépôt et à la diffusion de documents scientifiques de niveau recherche, publiés ou non, émanant des établissements d'enseignement et de recherche français ou étrangers, des laboratoires publics ou privés. 
Version définitive du manuscrit publié dans / Final version of the manuscript published in: Plant Pathology, 2013, 62, 657-666. DOI: 10.1111/j.1365-3059.2012.02666.x. The manuscript is available at http://onlinelibrary.wiley.com/doi/10.1111/j.13653059.2012.02666.x/full

\title{
Field models for the prediction of leaf infection and latent period of Fusicladium oleagineum on olive based on rain, temperature and relative humidity
}

\author{
C. Roubal ${ }^{\mathrm{a}}$, S. Regis ${ }^{\mathrm{a}}$ and P.C. Nicot $^{\mathrm{b}}$ \\ Address: \\ a SRAAL-DRAAF PACA. Quartier Cantarel, BP 95, F-84143 Montfavet CEDEX. France. \\ christophe.roubal@agriculture.gouv.fr \\ b INRA, UR407 Pathologie végétale, F-84140 Montfavet, France. \\ philippe.nicot@avignon.inra.fr
}

\begin{abstract}
Although much is known on the effect of climatic conditions on the development of peacock leaf spot of olive, field-operational models predicting disease outbreaks are lacking. With the aim of developing such models, a 10-year survey was conducted to relate leaf infection to climate parameters that can be easily monitored in the field. As outbreaks of disease are known to be linked to rain, models were evaluated for their ability to predict whether infection would occur following a rain event, depending on air temperature and duration of relative humidity above 85\%. We examined a total of 134 rain events followed by confirmed leaf infection and 191 rain events not followed by detectable infection. The field data were adequately fitted (both specificity and sensitivity $>0.97$ ) with either a multilayer neural network or with 2 of 6 tested regression models describing high boundary values of high humidity duration, above which no infection occurred over the temperature range, and low boundary values below which no infection occurred. The data also allowed the selection of a model successfully relating the duration of latent period (time between infection and the first detection of leaf spots) as a function of air temperature after the beginning of rain $\left(\mathrm{R}^{2}>0.98\right)$. The predictive abilities of these models were confirmed during two years of testing in commercial olive orchards in southern France. They should thus provide useful forecasting tools for the rational application of treatments and foster a reduction in fungicide use against this major disease of olive.
\end{abstract}

Additional keywords: Olea europaea; integrated pest management; decision support system

\section{Introduction}

Peacock leaf spot, sometimes also referred to as olive scab, olive leaf spot or cycloconium leaf spot, is one of the most common diseases of olive (Olea europaea) trees worldwide (Obanor et al., 2008b). Its causal agent, formerly Spilocaea oleaginea (Castagne) S. Hughes, syn. Cycloconium oleagineum Castagne, was recently assigned to Fusicladium oleagineum (Castagne) Ritschel \& U. Braun on the basis of morphological and genotypic traits (Crous et al., 2007; Schubert et al., 2003, Sergeeva et al., 2009). Leaf symptoms consist of brown, circular and often zonate spots eventually surrounded by a yellow halo (Zarco et al., 2007). Over time, the leaves become chlorotic and defoliation may occur, which can significantly weaken the plant and reduce fruit yield on heavily infected trees (Graniti, 1993). It can also affect the quality of the fruits and can decrease the oil yield (Graniti, 1993). Most of the cultivars used for production are susceptible, even if a large range of disease prevalence can be observed among cultivars (MacDonald et al., 2000). On susceptible cultivars in conditions favourable for disease development, the protection relies heavily on chemical control. In such situations in New Zealand, up to six sprays may be applied per year, corresponding to a total application of over 6 
kg of copper per ha (Obanor et al., 2008b). We have also observed such levels of copper use in France in some orchards planted with the most susceptible cultivars in areas where climatic conditions are particularly favourable to disease development (unpublished data).

The infections result from the germination of conidia on the surface of the leaves. The fungus rapidly penetrates the thick cuticle of the olive leaf and develops a colony, restricted to the subcuticular area of the epidermis, leading to the formation of a stroma (Graniti, 1993). The lesions remain undetectable to the naked eye until conidiophores are produced on the stroma, breaking the cuticular layer, and sporulation occurs (Graniti, 1993). The conidia are disseminated by wind (Lops et al., 1993) and rain (Tenerini, 1964) and can, in turn, produce new lesions. As olive is an evergreen tree, numerous cycles can take place year-round whenever conditions are favourable to disease development in the orchard. Contrary to the situation for apple scab, caused by a related species (Gadoury \& Mac Hardy, 1982), no evidence has been reported for any epidemiological role of a hypothetical sexual stage in F. oleagineum. Furthermore, recent studies on the genotypic diversity of this fungus support the predominance of asexual reproduction (Obanor et al., 2010a).

Outbreaks of disease are strongly linked to rain events (Loussert \& Brousse, 1978) and studies have been conducted on the effect of temperature and relative humidity on the infection process and on the latent period before symptom expression. Leaf infections were reported to occur at relative humidity conditions as low as $80-85 \%$ (Chen \& Zhang, 1983) but in most cases, wetness appeared to be necessary (Graniti, 1993; Loussert \& Brousse 1978; Pappo \& Pelec, 1958). The minimum duration of leaf wetness was estimated to vary between one and two days depending on the temperature, within a range of $5^{\circ} \mathrm{C}$ to $25^{\circ} \mathrm{C}$ (Graniti, 1993). The widest reported range of temperature conducive to conidial germination was from $2^{\circ} \mathrm{C}$ to $34^{\circ} \mathrm{C}$ (Graniti, 1993), with an estimated optimum between $12^{\circ} \mathrm{C}$ and $15^{\circ} \mathrm{C}$ (Loussert \& Brousse, 1978) or between $16^{\circ} \mathrm{C}$ and $22^{\circ} \mathrm{C}$ (Chen \& Zhang, 1983; Graniti, 1993). The time needed for symptom expression following leaf infection (referred to as "latent period" in this work) was also reported to be highly dependent upon temperature, ranging from 12 days at $16-20^{\circ} \mathrm{C}$ to $16-19$ days at $21-$ $25^{\circ} \mathrm{C}$ (Chen \& Zhang, 1983). In very hot or very cold conditions, the latent period was estimated to last for several weeks or even several months (Miller, 1949; Graniti, 1993) and this resulted in autumn infections which caused leaf spots that did not develop until the next spring or summer (Graniti, 1993).

Such knowledge of conditions favourable to disease development can be very useful to limit the application of fungicides according to the risk of infection. In the last ten years, comprehensive multifactorial studies conducted in precisely controlled conditions have provided a useful basis for the construction of multiple regression models which characterize the relationships between disease severity or key steps of the disease cycle and environmental factors. A third-order polynomial equation was used to describe disease severity as a function of air temperature and the duration of leaf wetness (Viruega \& Trapero, 2002), and second-order polynomial equations were used to describe spore germination or appressorium formation as affected by temperature and leaf wetness duration and for modelling the kinetics of germ tube growth for 180 hours at each of five temperature levels (between 5 and $25^{\circ} \mathrm{C}$ ) under continuous wetness (Obanor et al., 2008a). More recently, Obanor et al. (2010b) proposed a second-order polynomial model relating disease severity (estimated by the number of spots on batches of leaves examined on potted plants) to wetness duration, temperature and leaf age. They also showed that in conditions of continuously high relative humidity (98\% or higher) the quantitative relationship between disease severity and inoculum concentration was adequately represented by logistic equations for five different temperature levels between 5 and $25^{\circ} \mathrm{C}$. The effect of wetness interruption and the effect of wetness duration prior to a 12 hour dry period were also modelled with second-order polynomial equations for experiments conducted at either 10 or $20^{\circ} \mathrm{C}$.

Such data constitute tremendous progress in our comprehension of the epidemiology of the disease and provide key information for the development of risk prediction models in the field. 
In our attempts to develop such a model, however, we were confronted with difficulties in measuring leaf wetness duration accurately and in a way that would be representative for most of the canopy in an orchard. To date, no wetness sensors have been endorsed by the World Meteorological Organization (Anonymous, 2008) and studies in orchards have shown that wetness assessment is highly influenced by the position of the sensors on the trees (Sentelhas et al., 2005). Furthermore, reported correlations between visual observations and information provided by wetness sensors can be low with $\mathrm{R}^{2}$ coefficients below 0.6 (Magarey et al., 2006).

As a consequence, a different approach was initiated to develop predictive models for infection events and for the duration of the latent period, based on field-measured relative humidity, rain duration and temperature. As infections are strongly related to rain in the field, the aim of our work was to identify the associated risk factors that could be easily integrated into an operational decision support system. The specific objectives of the present study were (i) to identify climatic conditions that are needed, in addition to the presence of rain, to produce leaf infection in the field, and (ii) to estimate the duration of the latent period as a function of air temperature and relative humidity.

\section{Materials and Methods}

\section{Experimental orchard}

The study was conducted from 1999 to 2009 in the Baux-de-Provence production area in southern France in a 2 ha commercial olive orchard located at an altitude of $50 \mathrm{~m}$ above sea level. The orchard was planted in 1960 with cultivar Grossane, which is one the most susceptible to F. oleagineum among cultivars grown in France. The trees were pruned in a traditional vase shape. They were not irrigated and were cultivated according to local organic farming practices. Within this orchard, we used a 70-tree experimental plot which had received no pesticide treatment since 1990. On 30 March 1999 at the beginning of the experiment, disease symptoms were present on $8 \%$ of the leaves in the experimental plot. In the surrounding orchard, disease was only detected in a few areas, where a maximum of $2 \%$ of the leaves were infected.

\section{Monitoring of climatic data}

Data were collected from a weather station (CIMEL 140, CIMEL Electronique, Paris, France) managed by a local administration ("Comité Economique Agricole de l'Olivier" at Aix en Provence). Located among olive trees $50 \mathrm{~m}$ south-east of the experimental plot, this weather station was equipped with sensors which allowed continuous recording of air temperature, relative humidity (RH) and rain intensity (in mm per hour for rain events $>0.2 \mathrm{~mm}$ ).

\section{Disease assessment}

Ten trees were selected in the center of the experimental plot and marked for future observations. They were examined one to three times a week between January 1999 and December 2004. From each tree, 10 fully expanded leaves (3-12 months old) were collected at random and examined for symptoms. As a result, 100 leaves were examined for every observation date. This sample size was chosen as an empirical compromise between the need for feasibility of frequent field surveys and the aim to minimize the risk of missing small increases in disease incidence. Each time, the number of leaves with visible spots was recorded and leaves without visible spots were processed to reveal latent infections. We used a method somewhat similar to that developed by Zarco et al. (2007). The leaves were incubated for 30 minutes in $15 \% \mathrm{KOH}$ at $18-$ $22^{\circ} \mathrm{C}$. Following this treatment, a leaf was considered as infected if at least one translucent spot was revealed (Figure 1). 


\section{Linking rain events and leaf infection events}

Rain is indispensible for leaf infection to occur, but certain rain events may not result in infection if available inoculum is insufficient or if microclimatic conditions are not favourable. The basis of our study was to examine 376 rain events (recorded between 1999 and 2009) and determine which of them resulted in subsequent infection. Two iterative steps were used to achieve this purpose. In the first step, we used threshold values of temperature and wetness duration provided by previous studies to identify situations conducive to infection and situations for which infection was not possible. A rain was considered to be "non-infectious" in two situations: (i) if it occurred when air temperature was below $6{ }^{\circ} \mathrm{C}$ (based on data of Chen \& Zhang, 1983) or (ii) if it was followed by a high humidity period (RH $>85 \%$ ) shorter than 6 hours. A rain was considered as "infectious" (presuming that inoculum was present) if it occurred when air temperature was between $10^{\circ} \mathrm{C}$ and $20^{\circ} \mathrm{C}$ (based on data of Obanor et al., 2010b) and when it was followed by a high humidity period ( $\mathrm{RH}>85 \%)$ longer than 12 hours. This first step resulted in the identification of unambiguous situations (either clearly infectious or clearly non-infectious rain events). For the remaining ambiguous rain events, a second iterative step was carried out to remove the ambiguity.

The second iterative step involved a detailed comparative examination of the weather data and the disease incidence data over the days following each of these ambiguous rain events. We compared the dates of emergence of new leaf spots with the estimated duration of the latent period following each of these rain events. The method used to estimate the duration of the latent period as a function of temperature and air humidity will be described below. When the estimated latent period elapsed without any emergence of leaf spots, the rain event was regarded as "non-infectious". Conversely, a rain event was regarded as clearly "infectious" if an outbreak of lesions occurred during the estimated latent period that followed and if no other rain events occurred during that period. It was thus possible to identify additional infectious or noninfectious events, leading to a substantially larger total data set. However, it was sometimes impossible to define whether a rain event was responsible for a subsequent outbreak of disease, for example when several rain events occurred within a short time span before the observation of new symptoms. Such unresolved ambiguous cases were excluded from the rest of the study.

\section{Relating the duration of the latent period with air temperature after an infection event}

An estimate for the duration of the latent period was a necessary tool to reduce the number of ambiguous cases described in the second iterative step above. The basis for establishing this estimate was the set of "infectious" rain events clearly identified in the first iterative step above. For each of these rain events, the duration of the latent period was compared to the average air temperature during the time between the beginning of the rain and the field observation of the associated peacock spots. Regression analysis was used to fit second to sixth order polynomial models to the data. The goodness-of-fit of the models was compared on the basis of the correlation coefficients and the standard errors of the estimates computed as $S E E_{R}=\sqrt{\frac{\sum(\text { Yobs }- \text { Yest })^{2}}{n-k}}$, where $Y_{o b s}$ and $Y_{\text {est }}$ were the observed and model-estimated values, respectively, $n$ was the total number of data points and $k$ the degrees of freedom of the model. The distributions of residuals were also examined as routinely carried out in regression analysis. The best model was then used in the second iterative step described above, leading to an enlarged set of infectious rain events. This final set of data was then used to conduct a second round of regression analysis, using the same types of models, in order to further refine the latent period model.

\section{Relating the occurrence of infection with air temperature during rain and duration of high relative humidity following rain events}


Two methods were used for the analysis of data associated with the set of infectious and noninfectious rain events. One method consisted of regression analysis and the second method consisted of fitting neural network models.

\section{Regression analysis}

In a first step, an exploratory analysis of the data was realized by constructing a graph (Figure 2) plotting rain events according to the average temperature recorded during the rain (TR; $X$ axis) and the duration of high relative humidity after the rain (DHRH; Y axis), quantified as the number of hours with high relative humidity $(\mathrm{RH}>85 \%)$. Infectious rain events were distinguished from non-infectious rains, revealing conditions favourable to infection, conditions clearly not conducive to infection and "ambivalent conditions" for which both infectious and non-infectious rains were present.

In the second step we determined, across the range of recorded temperatures, two sets of boundary values. One set of boundary values represented the shortest durations of high humidity associated with infectious rains and the second set represented the longest durations of high humidity associated with non-infectious rains (Figure 2).

The third step consisted in fitting regression models to the boundary values identified in step two, in order to characterize the critical condition curve above which a rain was always infectious and the curve below which a rain was never infectious. Regression analysis was realized with the help of CurveExpert 1.3 software. Among the types of models available for evaluation with this software, six were selected for comparison (Table 1) because they provided curves with a high negative slope at low X values and a general L or U shape (Perner, 2007; Seber \& Wild, 1989) as shown by the data points (Figure 2). The goodness-of-fit of the models was compared on the basis of the correlation coefficients, the standard errors of the estimates and the distribution of residuals, as indicated above. In addition, the Akaike Information Criterion (Akaike, 1969) was computed as $A I C=n \log (S S E / n)+2(p+1)$, where SSE was the sum of squared errors $S S E=\Sigma\left(Y_{o b s}-Y_{e s t}\right)^{2}$ and $p$ was the number of estimated parameters of a model.

\section{Artificial neural network models}

The data were also analysed using a multilayer feed-forward neural network (Peacock et al., 2007) to provide an appraisal of the occurrence of infection following a rain event. Tanagra software (available from the website: http://eric.univ-lyon2.fr/ ricco/tanagra/en/tanagra.html) was used with the same two variables as in the regression analysis above (TR and DHRH). The neural network was run with the standardized values of these variables ([raw value average]/standard deviation), two neurons in the hidden layer and the learning parameters and stopping rules shown in Table 2. Its performance was evaluated by computing the overall prediction success, the sensitivity and the specificity as described by Peacock et al., 2007.

\section{Results}

\section{Progress of infection over time}

The observed incidence of leaves with typical peacock spots (visible infections) in the orchard varied widely over the ten-year study (0 to nearly $70 \%$; Figure 3 ). When taking into account the latent infections revealed by the laboratory test (referred to as "total infections"), the maximum incidence reached $90 \%$. Reductions in the number of diseased leaves in the orchard were associated with defoliation, due to natural senescence of the leaves or disease-related abscission. This phenomenon was occasionally amplified by episodes of strong winds (wind speed $>70$ $\mathrm{km} . \mathrm{hr}^{-1}$; Figure 3). 


\section{Linking rain events and leaf infection events}

The first iterative step resulted in the unambiguous identification of 63 infectious and 165 noninfectious rain events among the 376 rain events examined.

The second iterative step allowed the identification of 71 additional infectious events and 26 non-infectious events, leading to a total data set of 134 infectious and 191 non-infectious rain events. The remaining unresolved ambiguous cases (excluded from the rest of the study) amounted to 51 out of a total of 376.

\section{Relating the duration of the latent period to air temperature after an infection event}

The final polynomial regression analysis was carried out on the total data set of 134 infectious rain events. Fitness improvement beyond the fourth degree polynomial was marginal (Figure 4). The equation for this model, represented in Figure 5, was:

$D i=364.76-89.57 * T i+9.12 * T i^{\wedge} 2-0.43 * T i \wedge 3+0.0078 * T i \wedge 4$,

where $\mathrm{Di}$ and $\mathrm{Ti}$ represented the duration of the latent period and the average temperature during the period from leaf infection until symptom expression, respectively.

\section{Relating the occurrence of infection to air temperature during rain and duration of high relative humidity following rain events}

Regression models

Among the six models tested, four adequately described both sets of boundary values defined in Figure 2 (critical conditions above which a rain was always infectious and those below which a rain was never infectious). The best fitness indicators were observed for the Logistic model (Table 1) and for the Vapor Pressure model whose graphic representation is shown on Figure 6.

\section{Neural network model}

The feed-forward multilayer neural network was successfully used to define a model assigning a correct infection status to all but two of the 325 rain events examined in the study, resulting in a sensitivity value of 0.985 . All rain events not followed by infection were correctly identified, resulting in a specificity value of 1 . The parameters of this model are described in Table 3 . Based on the model, a curve was constructed to delineate the critical high humidity duration above which infection could occur over the temperature range (Figure 6).

\section{Discussion}

The analysis of the large data set collected in our 10-year study, using the results from previous work in controlled conditions (Viruega \& Trapero, 2002; Obanor et al., 2008a; Obanor et al., 2010b), allowed the successful fitting of models relating field-measured climate data to the occurrence of olive leaf infection by $F$. oleagineum and to the duration of the latent period following infection. To our knowledge, this is the first successful exploitation of field data on olive peacock spot to develop predictive models.

Two very different approaches were used for modelling leaf infection. The regression approach required the selection and separate analysis of two sets of boundary values (representing, respectively, the shortest durations of high humidity associated with infectious rains and the longest durations of high humidity associated with non-infectious rains). In contrast, the neural approach used the global data set, without any need for preliminary interpretation of the data, and provided a single boundary separating infectious and noninfectious rain events. Despite this advantage and its wide use for pattern or voice recognition, this type of model is still seldom used for plant protection studies (Peacock et al., 2007). Interestingly, the predictive curves provided by the two approaches were quite similar in shape 
(Figure 6) and the sensitivity and specificity of the models were similarly high (Table 4). This supported a posteriori the choices made in the present study to distinguish the critical high and low boundary values (Figure 2). For practical field application, however, the models provided by the regression approach were preferred for further work. The reason for this choice was that the difference in specificity and sensitivity of the two complementary curves (Table 5) allows the operator to select a model depending on an appreciation of the field situation and the level of acceptable risk. Using the curve showing low boundary values for infection (Figure 6) as a decision threshold can lead to possible under-estimation of the infection risk. In contrast, using the curve showing high boundary values for non-infection can lead to possible over-estimation of the infection risk.

Among the six models used in the regression analysis of the high and low boundary values, two clearly provided the best fits: the logistic model and the vapour-pressure model. Although the fitness indicators were slightly higher for the logistic model (Table 1), we selected the vapour-pressure model for the development of a predictive tool. The reason which guided this choice was that the curves fitted to our data with the logistic model intersected at low temperatures (X axis), casting a doubt on their biological legitimacy because they delineated a zone where a rain event should be both infectious and non-infectious at the same time. The vapour-pressure model did not present this drawback. Interestingly, the curves fitted with this model (Figure 6), although they only pertain to infection vs non-infection, present a strong analogy in shape with those of the model recently used by Viruega et al. (2011) to describe disease severity according to wetness duration and temperature in a controlled environment study.

Several future improvements in the predictive tool could be envisioned. Beyond knowing if weather conditions are conducive for infection to occur, the growers may wish to modulate the timing of their fungicide applications depending on the severity of the ensuing disease in the field. The recently established relationship between disease severity and climatic parameters (Viruega et al., 2011) constitutes a remarkable step toward such a goal. Several additional factors would need to be considered in the field, including the susceptibility of the olive cultivar (MacDonald et al., 2000) and inoculum pressure. The quantitative role of inoculum pressure has clearly been shown in controlled environment studies, both in terms of disease incidence and disease severity (Obanor et al., 2010b; Viruega et al., 2011). For intensively studied diseases such as Botrytis leaf blight of onion, direct field assessment of airborne inoculum has been used in conjunction with weather-based disease prediction models (Van der Heyden et al., 2012). Alternatively, indirect estimates of inoculum pressure might also be simpler to implement in a field situation in the case of olive peacock. For example, quantifying the frequency of leaf infection on the trees might provide sufficient information for modelling purposes as fallen leaves in the orchard are not expected to liberate substantial amounts of inoculum (Prota, 1958; Laviola, 1966). Implementing such improvements, however, might not be sufficient as other complex factors may also be implicated in disease severity. For example, classes of leaf age would need to be distinguished, as most damaging infections were reported to occur in the spring (Shabi et al., 1994), possibly because the susceptibility of a leaf varies significantly with its age (Viruega et al., 2011). This in turn would also require the establishment of models to describe the production of new leaves by the trees as well as their life span and the factors which influence their final abscission, providing an additional level of complexity. Although desirable, such improvements of the risk prediction tools may be difficult to achieve soon in practice. Even for better-known diseases such as apple scab, to which much modelling effort has been devoted, quantification of risk has long been limited to predicting the release of primary inoculum according to climatic factors (Gadoury \& MacHardy, 1982; Giosuè et al., 2000), suggesting that difficulties were encountered for the development of predictive tools taking disease severity into account. More recent advances include models attempting to predict scab severity based on host susceptibility and phenological stage as well as climatic factors (Rossi et al., 2007). However, modelling the severity of apple scab is complicated by at least two factors. One is the 
implication of both a sexual and an asexual form of inoculum. The second one is the difficulty in predicting the survival of pseudothecia and the amount of viable ascospores that they carry (Gadoury \& MacHardy, 1986; Holb, 2006). This remains to be demonstrated, but faster progress could be anticipated for peacock leaf spot of olive as its epidemiology is somewhat simpler (due to the absence of sexual reproduction) and there is hope that the amount of conidial inoculum could be inferred from by the number of diseased leaves present on the trees of an orchard.

In conclusion, despite (or possibly thanks to) their simplicity, the models obtained in the present study appear to constitute a promising tool for practical field application. During a 2year period of field validation (2009-2011) by the French Phytosanitary Advisory Service over a sample of 40 sites in the French olive-growing region, each encompassing a 1-km radius around a weather station, only one infection failed to be predicted (unpublished data). That particular infection event could not be linked to any detected rain. It was thus probably the result of a very short rain $(<0.5 \mathrm{~mm})$ which failed to be detected by the sensor. With this single exception, the robustness of the predictive tool appears promising, although it cannot be excluded that growers may have failed to detect minor infection events, associated with very low increases in disease incidence. It is not possible to evaluate the frequency of falsely predicted infections, as growers sprayed in response to a predicted infection if they considered that current fungicide coverage was insufficient. The models are also currently used, together with archive meteorological data from 140 weather stations, to map the risk of olive peacock disease in Southern France according to the average yearly number of infectious rains.

\section{Acknowledgements}

We thank the Centre d'Information Régional Agrométéorologique (CIRAME), the French Economic Committee of Olive (CEO), the French Interprofessional Olive Association (AFIDOL) and the Mas-de-la-Dame for facilitating data acquisition for the present study.

\section{References}

Akaike H, 1969. Fitting Autoregressive Models for Prediction. Annals of the Institute of Statistical Mathematics 21, 243-47.

Anonymous, 2008. Measurement of dew and leaf wetness. Chapter 6.6.1 In: World Meteorological Organization Guide to meteorological instruments and methods of observation, $\mathrm{N}^{\circ} 8$ (seventh edition), $677 \mathrm{p}$.

Chen S, Zhang J, 1983. Studies on olive peacock's eye disease, Infection cycle and epidemiology. Acta Phytopathologica Sinica 13 (1), 31-40.

Crous PW, Schubert K, Braun U, de Hoog1 GS, Hocking AD, Shin H-D, Groenewald1 JZ, 2007. Opportunistic, human-pathogenic species in the Herpotrichiellaceae are phenotypically similar to saprobic or phytopathogenic species in the Venturiaceae. Studies in Mycology 58, 185-217.

Gadoury DM, MacHardy WE, 1982. A Model to Estimate Maturity of Ascospores of Venturia inaequalis. Phytopathology 72, 901-4.

Gadoury DM and MacHardy WE, 1986. Forecasting ascospore dose of Venturia inaequalis in commercial apple orchards. Phytopathology 76: 112-118.

Giosuè S, Rossi V, Ponti I, Bugiani R, 2000. Estimating the dynamics of airborne ascospores of Venturia inaequalis. OEPP Bulletin 30, 137-142.

Graniti A, 1993. Olive scab: a review. EPPO Bulletin 23, 377-84.

Holb I, 2006. Effect of six sanitation treatments on leaf litter density, ascospore production of Venturia inaequalis and scab incidence in integrated and organic apple orchards. European Journal of Plant Pathology 115, 293-307. 
Laviola C, 1966. Contribution to the knowledge of the biology of Spilocaea oleagina (Cast.) Hugh. in Apulia: Proceedings of the First Congress of the Mediterranean Phytopathological Union. Bari, Italy: MPU, 327-39.

Loussert R, Brousse G, 1978. L'olivier, Paris, France : G.P. Maisonneuve et Larose, 318-20.

Lops F, Frisullo S, Rossi V, 1993. Studies on spread of the olive scab pathogen, Spilocaea oleagina. EPPO Bulletin 23, 385-87.

MacDonald AJ, Walter M, Trought M, Frampton CM, Burnip G, 2000. Survey of olive leaf spot in New Zealand. New Zealand Plant Protection 53, 126-32.

Magarey RD, Seem RC, Russo JM, 2006. Grape canopy surface wetness : simulation versus visualisation and measurement. Agricultural and Forest Meteorology 139, 361-372.

Miller HN, 1949. Development of the leaf spot fungus in the olive leaf. Phytopathology 39, 40310.

Obanor FO, Walter M, Jones EE, Jaspers MV, 2005. Sources of variation in field evaluation of the incidence and severity of olive leaf spot. New Zealand Plant Protection 58, 273-7.

Obanor FO, Walter M, Jones EE, Jaspers MV, 2008a. Effect of temperature, relative humidity, leaf wetness and leaf age on Spilocaea oleagina conidium germination on olive leaves. European Journal of Plant Patholology 120, 211-222.

Obanor FO, Walter M, Jones EE, Jaspers MV, 2008b. Greenhouse and field evaluation of fungicides for control of olive leaf spot in New Zealand. Crop Protection 27, 1335-42.

Obanor FO, Walter M, Jones EE, Candy J, Jaspers MV, 2010a. Genetic variation in Spilocaea oleagina population from New Zealand olive groves. Australasian Plant Pathology 39, 50816.

Obanor FO, Walter M, Jones EE, Jaspers MV, 2010b. Effects of temperature, inoculum concentration, leaf age, and continuous and interrupted wetness on infection of olive plants by Spilocaea oleagina. Plant Pathology 60, 190-199

Pappo S, Pelec J, 1958. La maladie "cycloconium" sur l'olivier et la lutte contre cette maladie : Proceedings of the first Conférence Internationale des Techniciens oléicoles. Tanger, Algérie : 473-488.

Peacock L, Worner S, Pitt J, 2007. The application of artificial neural networks in plant protection. EPPO Bulletin 37, 277-82.

Perner P, 2007. Advances in Data Mining. Theoretical Aspects and Applications: Proceedings of the $7^{\text {th }}$ industrial conference. July 14-18, 2007, Leipzig, Germany: Springer-Verlag.

Prota U., 1958. Contribution to the pathology of the cultivated olive in Sardinia. I. Observations and investigations on the "peacock's eye" induced by Cycloconium oleagineum: infection period, appearance and evolution of leaf spots; phylloptosis; conidiogenesis. Studi Sassaresi. Sez. III Annali della facoltà di Agraria. Universita di Sassari 6, 256-288.

Rossi V, Giosuè S, Bugiani R, 2007. A-scab (Apple-scab, a simulation model for estimating risk of Venturia inaequalis primary infections. EPPO Bulletin 32, 300-308.

Schubert K, Ritschel A, Braun U, 2003. A monograph of Fusicladium s.lat. (Hyphomycetes). Schlechtendalia 9, 71-132.

Seber GAF, Wild CJ, 1989. Growth models. In: Nonlinear regression. New York, USA: John Wiley \& sons.

Sergeeva V, Braun U, Spooner-Hart R, Nair NG, 2009. Observations on spot caused by Fusicladium oleagineum on olives (Olea europaea) in New South Wales, Australia. Australasian Plant Disease Notes 4, 26-28.

Sentelhas PC, Gillespie TJ, Batzer JC, Gleason ML, Monteiro JEBA, Pezzopane JRM, Pedro MJ, 2005. International Journal of Biometeorology 49, 363-370.

Shabi E, Birger R, Lavee S, 1994. Leaf spot (Spilocaea oleagina) of olive in Israel and its control. Acta Horticulturae 356, 390-394.

Tenerini I, 1964. Richerche sulla biologia de epidemiologia della Spilocaea oleagina (Cast.) Hug., agente dell'occhio di pavone dell'olivo. Phytopathologia Mediterranea 3, 63-70. 
Van der Heyden H, Carisse O, Brodeur L, 2012. Comparison of monitoring based indicators for initiating fungicide spray programs to control Botrytis leaf blight of onion. Crop Protection 33, 21-28.

Viruega JR, Trapero A, 2002. Effect of temperature, wetness duration and leaf age on infection and development of leaf spot. Acta Horticulturae 586, 797-800.

Viruega JR, Roca LF, Moral J, Trapero A, 2011. Factors affecting infection and disease development on olive leaves inoculated with Fusicladium oleagineum. Plant Disease 95, 1139-46.

Zarco A, Viruega JR, Roca LR, Trapero A, 2007. Detección de las infecciones latentes de Spilocaea oleagina en hojas de olivo. Boletín de Sanidad Vegetal: Plagas 33, 235-48. 


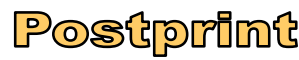

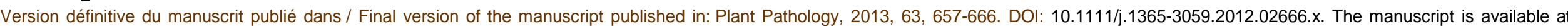
http://onlinelibrary.wiley.com/doi/10.1111/j.1365-3059.2012.02666.x/full

Table 1: Regression models fitted to the boundary values representing the shortest durations of high humidity associated with 'infectious' rains and the longest durations of high humidity associated with 'non-infectious' rains shown in Figure 2.

\begin{tabular}{|c|c|c|c|c|c|c|c|c|c|c|}
\hline \multirow[t]{2}{*}{ Model } & \multirow[t]{2}{*}{ Equation: } & \multicolumn{4}{|c|}{ high boundary for 'non-infectious' rains ${ }^{3}$} & \multicolumn{5}{|c|}{ low boundary for 'infectious' rains ${ }^{3}$} \\
\hline & & parameters & $\begin{array}{l}\text { Standard } \\
\text { Error }\end{array}$ & $\begin{array}{l}\text { Correlation } \\
\text { Coefficient }\end{array}$ & $\mathrm{AIC}$ & param & & $\begin{array}{l}\text { Standard } \\
\text { Error }\end{array}$ & $\begin{array}{l}\text { Correlation } \\
\text { Coefficient }\end{array}$ & $\mathrm{AIC}$ \\
\hline Logistic & $\mathrm{y}=\mathrm{a} /\left(1+\exp \left(\mathrm{b}-\mathrm{c}^{*} \mathrm{x}\right)\right)$ & $\begin{array}{r}4.8563 \\
-18.5796 \\
42.0620 \\
\end{array}$ & 0.938 & 0.986 & 6.517 & $\begin{array}{l}a= \\
b= \\
c=\end{array}$ & $\begin{array}{r}6.1582 \\
-1069.8436 \\
0.9398 \\
\end{array}$ & 0.418 & 0.996 & 0.939 \\
\hline Yapor Pressure & $y=\exp (a+b / x+c * \ln (x))$ & $\begin{array}{r}-16.4927 \\
72.8655 \\
4.8386\end{array}$ & 0.960 & 0.986 & 6.699 & $\begin{array}{l}a= \\
b= \\
c=\end{array}$ & $\begin{array}{r}-15.7267 \\
69.6551 \\
4.7098 \\
\end{array}$ & 0.589 & 0.989 & 3.322 \\
\hline $\begin{array}{l}\text { Reciprocal } \\
\text { Quadratic }\end{array}$ & $y=1 /(a+b * x+c * x / 2)$ & $\begin{array}{ll}\mathrm{a}= & -0.4106 \\
\mathrm{~b}= & 0.0798 \\
\mathrm{c}= & -0.0024 \\
\end{array}$ & 1.014 & 0.984 & 7.126 & $\begin{array}{l}a= \\
b= \\
c=\end{array}$ & $\begin{array}{r}-0.3951 \\
0.0767 \\
-0.0024 \\
\end{array}$ & 1.209 & 0.966 & 8.319 \\
\hline Weibull & $y=a-b * \exp \left(-c^{*} x d\right)$ & $\begin{array}{lr}\mathrm{a}= & 40.4053 \\
\mathrm{~b}= & 35.6332 \\
\mathrm{c}= & 1305233.5924 \\
\mathrm{~d}= & -7.3156 \\
\end{array}$ & 1.026 & 0.986 & 8.616 & $\begin{array}{l}a= \\
b= \\
c= \\
d=\end{array}$ & $\begin{array}{r}31.5441 \\
26.4244 \\
6106.7530 \\
0.5592 \\
\end{array}$ & 1.645 & 0.933 & 11.826 \\
\hline Hoerl & $y=a^{*}(b / x) *\left(x^{\prime} c\right)$ & $\begin{array}{lr}\mathrm{a}= & 1994069.7871 \\
\mathrm{~b}= & 1.6352 \\
\mathrm{c}= & -7.5738 \\
\end{array}$ & 1.126 & 0.981 & 7.945 & & & $\mathrm{ND}^{5}$ & ND & \\
\hline $\begin{array}{l}\text { Morgan - Mercer } \\
\text { - Flodin (MMF) }\end{array}$ & $y=(a * b+c * x d) /(b+x d)$ & $\begin{array}{lr}\mathrm{a}= & 2.1225 \\
\mathrm{~b}= & -84.0842 \\
\mathrm{c}= & 4.5523 \\
\mathrm{~d}= & 2.2513\end{array}$ & 1.052 & 0.986 & 8.811 & & & ND & ND & \\
\hline
\end{tabular}

${ }^{\alpha} \mathrm{y}=$ duration of period with air relative humidity $>85 \%$ from the start of a rain event $(\mathrm{h})$ and $\mathrm{x}=$ average air temperature during the rain $\left({ }^{\circ} \mathrm{C}\right.$ )

$\beta$ a rain event was considered as 'infectious' if it was followed by an increase in the incidence of peacock leaf spot within a time frame and conditions described in the Materials and Methods

${ }^{\gamma}$ Akaike Information Criterion

${ }^{\delta} \mathrm{ND}$ : not defined; the software was unable to fit this model to the data 
Version définitive du manuscrit publié dans / Final version of the manuscript published in: Plant Pathology, 2013, 63, 657-666. DOI: 10.1111/j.1365-3059.2012.02666.x. The manuscript is available at http://onlinelibrary.wiley.com/doi/10.1111/j.1365-

3059.2012.02666.x/full

Table 2: Parameters and rules used for the construction of a multilayer neural network describing the advent of leaf infection by Fusicladium oleagineum following rain events

\begin{tabular}{|rc|}
\hline \multicolumn{2}{|l|}{ Learning parameters } \\
\hline \multicolumn{2}{|c|}{ Validation set proportion } \\
\hline Learning rate \\
\hline Stopping rules \\
\hline Maximum number of iterations \\
\hline Error rate thresold \\
\hline Verify error stagnation \\
\hline
\end{tabular}

Table 3: Parameters of the fitted neural network model describing the advent of leaf infection by Fusicladium oleagineum following rain events

\begin{tabular}{|r|c|c|}
\hline \multicolumn{3}{|c|}{ Parameters for Input variable standardization } \\
\hline Variable & Average & Standard deviation \\
\hline $\mathrm{TR}^{\alpha}$ & 12.3566 & 4.4680 \\
\hline $\mathrm{DHRH}^{\beta}$ & 9.6559 & 6.6573 \\
\hline Weights from Input layer to Hidden layer \\
\hline$-\quad$ & Neuron 1 & Neuron 2 \\
\hline $\mathrm{TR}$ & -5.0460 & 0.4371 \\
\hline DHRH & -1.1489 & -5.6071 \\
\hline bias & -3.2367 & -3.8346 \\
\hline Weights from Hidden layer to Output layer \\
\hline$-\quad$ & no infection & infection \\
\hline Neuron 1 & 4.87441612 & -4.87440901 \\
\hline Neuron 2 & 5.30379161 & -5.30378556 \\
\hline bias & -2.694614 & 2.69461031 \\
\hline
\end{tabular}

${ }^{\alpha}$ TR: average temperature recorded during the rain

${ }^{\beta}$ Duration of high relative humidity $(\mathrm{RH}>85 \%)$ after the rain

Table 4: Specificity and sensitivity of the models selected to describe the advent of leaf infection by Fusicladium oleagineum following rain events.

\begin{tabular}{l|c|c|}
\hline Model $^{\alpha}$ & Specificity $^{\beta}$ & Sensitivity $^{\gamma}$ \\
\hline $\begin{array}{l}\text { Low threshold regression } \\
\text { model (Vapor Pressure } \\
\text { Model) }\end{array}$ & 1 & 0.977 \\
\hline $\begin{array}{l}\text { High threshold regression } \\
\text { model (Vapor Pressure } \\
\text { Model) }\end{array}$ & 0.974 & 1 \\
\hline Neural network model & \multicolumn{1}{|c|}{1} & 0.985 \\
\hline & & \\
$\beta$ & see Figure 3 for a description of the models \\
rate of correctly predicted absence of infection & \\
${ }^{\gamma}$ rate of correctly predicted infections
\end{tabular}




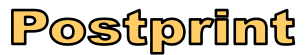

Version définitive du manuscrit publié dans / Final version of the manuscript published in: Plant Pathology, 2013, 62, 657-666. DOI: 10.1111/j.1365-3059.2012.02666.x. The manuscript is available at http://onlinelibrary.wiley.com/doi/10.1111/j.13653059.2012.02666.x/full

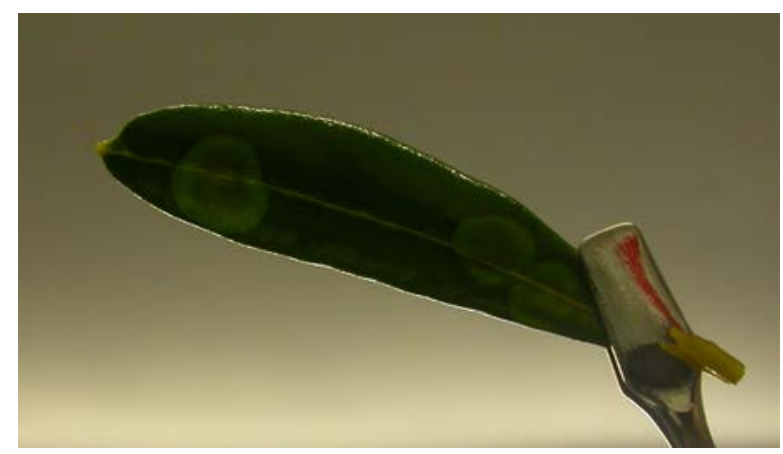

Figure 1: Latent infection of Fusicladium oleagineum (translucent spot) revealed by treatment of symptomless olive leaf with potassium hydroxide.

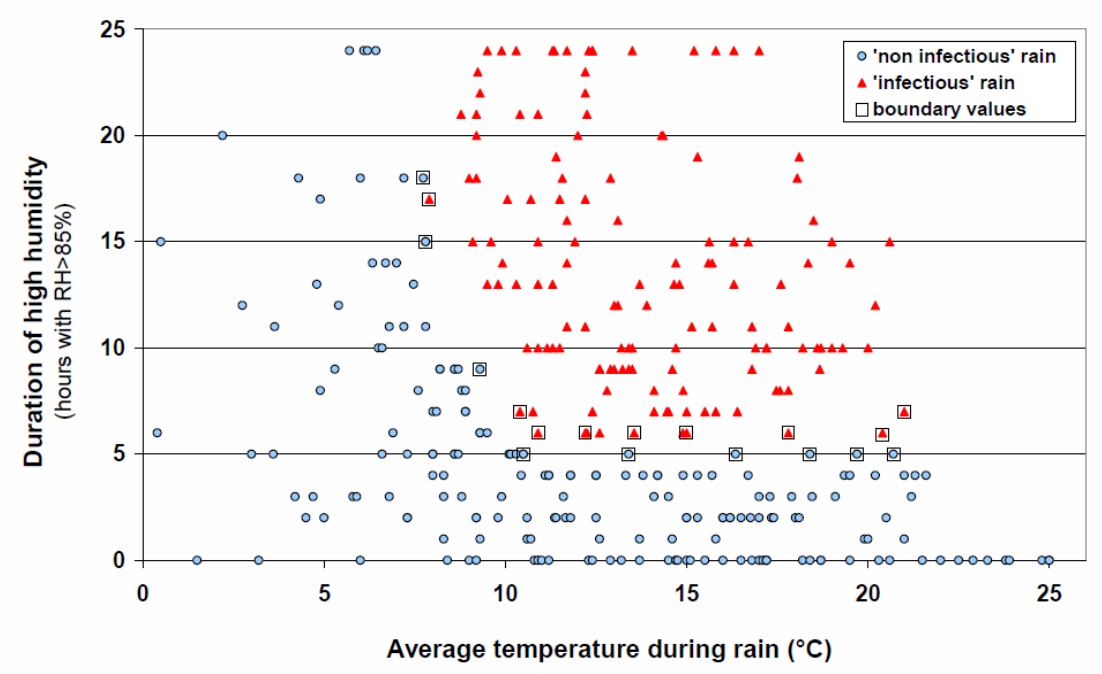

Figure 2: Characterisation of rain events according to temperature and duration of high relative humidity after rain onset. Each rain event was assigned an "infectious" status if it was followed by an increase in the incidence of peacock leaf spot within a time frame and conditions described in the Materials and Methods. Two sets of rain events were distinguished as boundary values. One set represented the rain events with the shortest durations of high humidity associated with infection and the second set represented the longest durations of high humidity associated with non-infectious rains. 


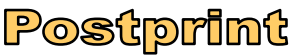

Version définitive du manuscrit publié dans / Final version of the manuscript published in: Plant Pathology, 2013, 62, 657-666. DOI: 10.1111/j.1365-3059.2012.02666.x. The manuscript is available at http://onlinelibrary.wiley.com/doi/10.1111/j.1365-

3059.2012.02666.x/full
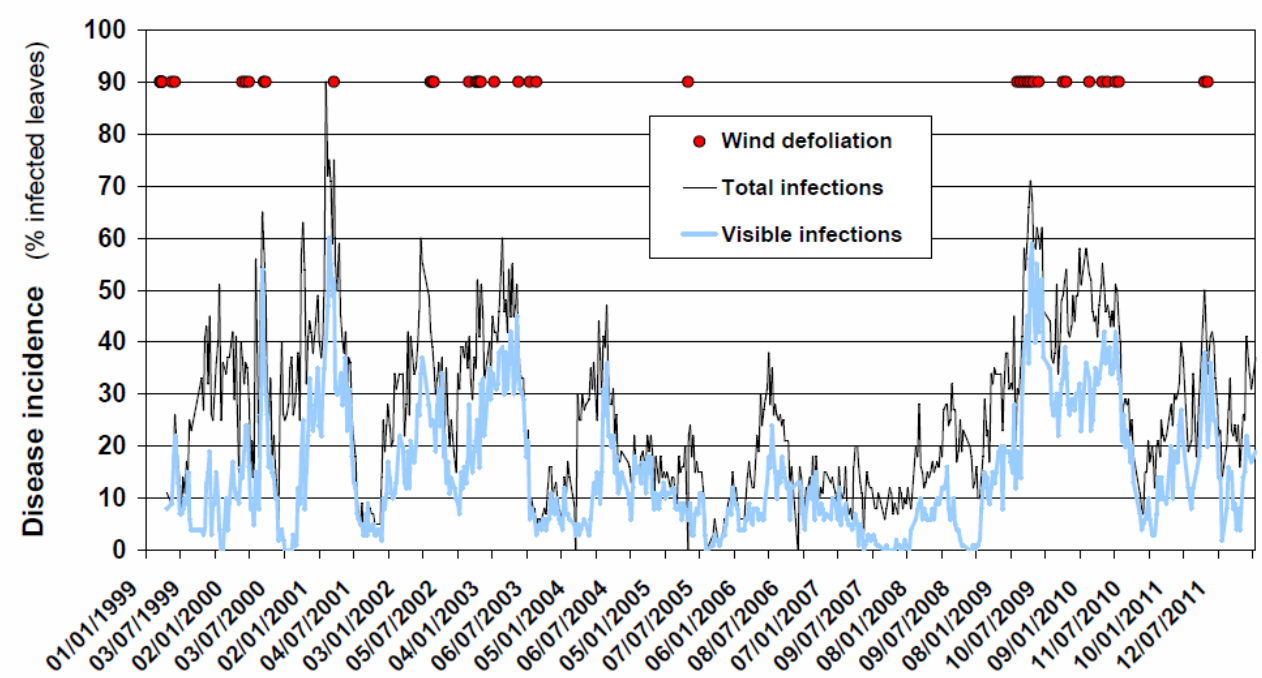

Figure 3: Progression overtime of Fusicladium oleagineum incidence (\% infected leaves). The lower curve (grey colour) represents leaves with typical peacock spots (visible infections). The upper curve (black colour) represents the total number of infected leaves, including those with latent infections revealed by laboratory tests. Individual dots on the upper part of the frame represent events of substantial leaf fall related with episodes of strong winds ( $>70 \mathrm{~km}$ per hour).

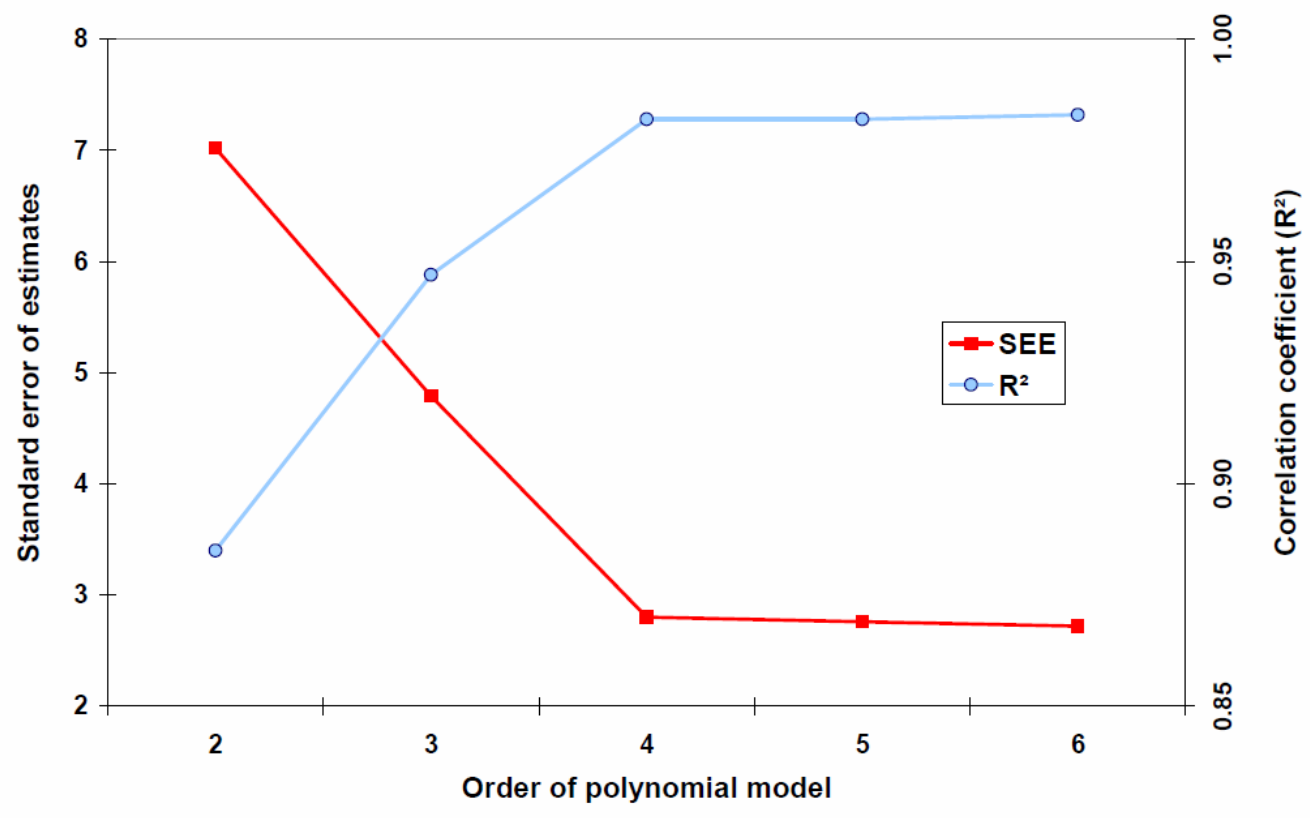

Figure 4: Relationship between goodness-of-fit indicators and the order of polynomial models relating the duration of peacock leaf spot latent period as a function of air temperature 


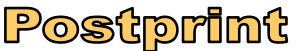

Version définitive du manuscrit publié dans / Final version of the manuscript published in: Plant Pathology, 2013, 62, 657-666. DOI: 10.1111/j.1365-3059.2012.02666.x. The manuscript is available at http://onlinelibrary.wiley.com/doi/10.1111/j.13653059.2012.02666.x/full

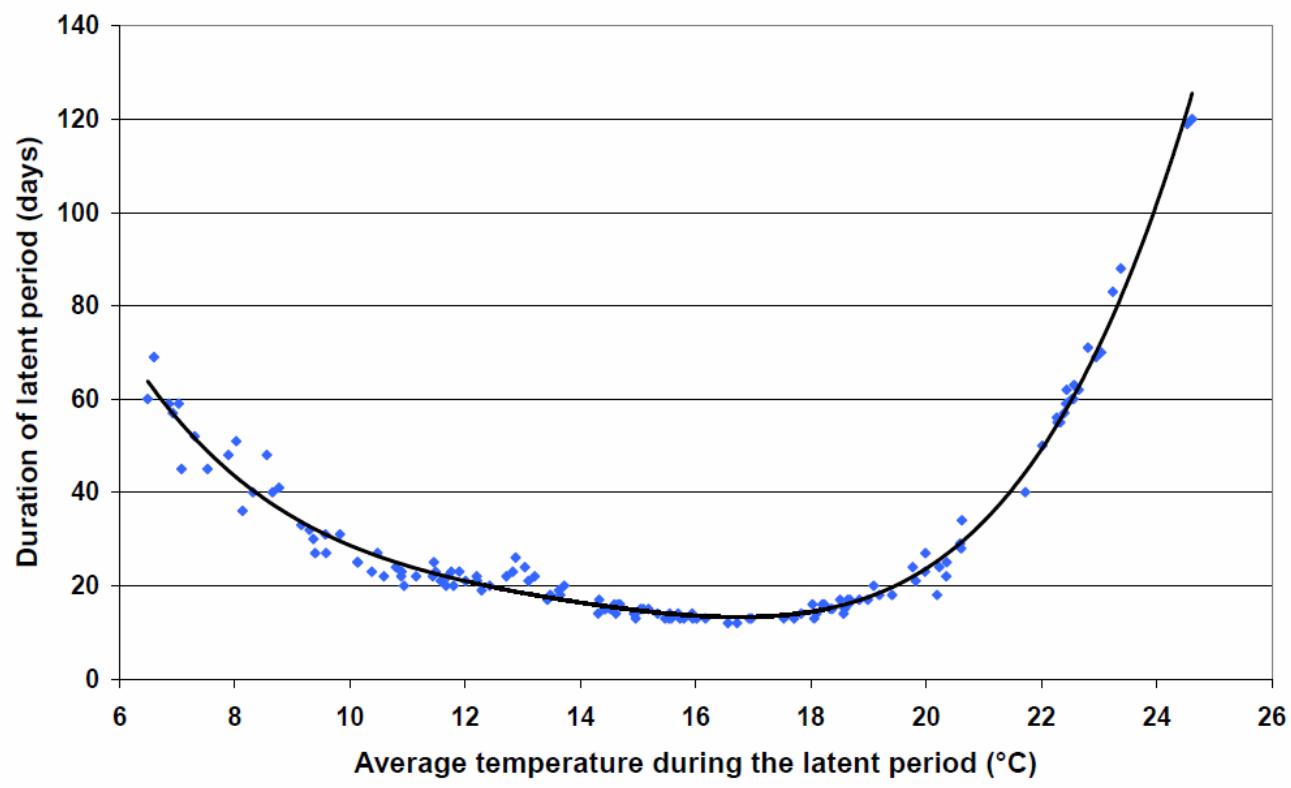

Figure 5: Relationship between the duration of the latent period and air temperature. Each data point represents an infectious rain event. The curve shows a $4^{\text {th }}$ order polynomial model fit to the data

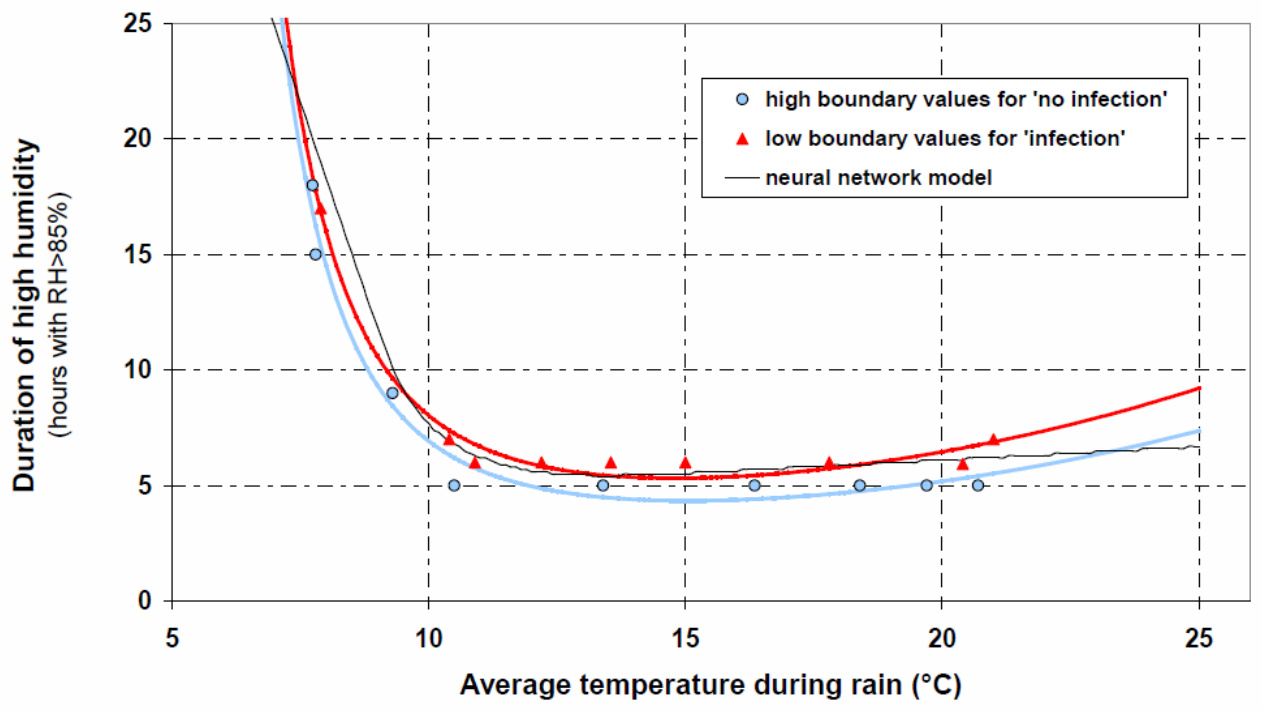

Figure 6: Predictive models for the infection of olive leaves by Fusicladium oleagineum according to temperature and duration of high relative humidity after rain onset. In addition to a multilayer neural network model, regression models were fitted to the boundary values representing the lowest durations of high humidity associated with "infectious" rains and the highest durations of high humidity associated with "non-infectious" rains. 